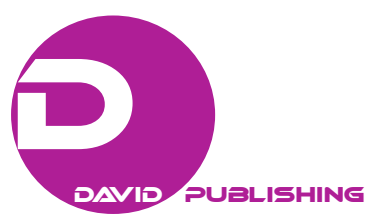

\title{
(The Good), The Bad and The Ugly: The Visual Construction of Female Child Sex-offenders
}

\author{
Charlotte Barlow, Adam Lynes \\ Birmingham City University, Birmingham, England
}

\begin{abstract}
This paper explores the visual construction and representation of female sex offenders. It utilises the case study of Vanessa George, a nursery worker who was involved in the exchange of indecent imagery of children via an online paedophile ring. The first part of the paper considers the emergence of the sub-discipline, visual criminology and examines what is known about the visual representation of female offenders. The second part presents the findings of an empirical investigation, which involved engaging in a critical, reflexive visual analysis of a selection photographs and the police mugshot of Vanessa George. The paper considers the ways in which George's physical appearance and her suggested ability to deceive were used to visually represent her as "other", thus reinforcing the existing simplistic motifs of female sex offending.
\end{abstract}

Keywords: female child sex offenders, visual representation

\section{Introduction}

In recent years within criminology there has been a growing recognition of the significance and "spectacle" of the image, emphasising the cultural, social, and political power of images of crime and criminal justice issues (For example, Rafter, 2014; Ferrell, Hayward, \& Young, 2008; Hayward \& Presdee, 2010; Carrabine, 2014). Photography in particular has captured the attention of criminologists since the work of Lombroso and Ferrero (1893), emphasising the denotative and connotative power of this form of imagery (Sekula, 1981, 1984; Barthes, 1977). Despite Lombroso and Ferrero's (1893) work being published during the Victorian period, it provides a useful insight into the myths and prejudices that remain to have a significant impact on the study of women and crime today, particularly in terms of dominant images of female offending (Lloyd, 1995).

In spite of this increasing recognition of the visual within criminology, there has been little research which explicitly explores the visual representation of women criminals. Much of the existing literature locates this analysis within a media representation context and considers the use of imagery in relation to image placement and page layout (Birch, 1993; Jones \& Wardle, 2008). Furthermore, particularly significant to this paper is that the visual construction of female sex offenders is distinctly absent from this discussion. Conversely, this paper applies a critical and reflexive approach to the visual construction of Vanessa George thus challenging the "bogus of positivism" associated with criminology (Young, 2011; Pink, 2007). It considers how photographs and mugshots may represent the cultural and social processes that underpin the construction and public understanding of female sex offenders. This paper not only seeks to deconstruct the images of George, but to

Charlotte Barlow, Ph.D., Lecturer in Criminology, School of Social Sciences, Birmingham City University.

Adam Lynes, Ph.D., Lecturer in Criminology, School of Social Sciences, Birmingham City University. 
also use the images as an introduction to a discussion about the over-simplistic, partial and androcentric construction of female sex offenders more broadly.

\section{Visual Criminology and the Image}

Criminology, despite its multi and cross- disciplinary nature, has struggled to build and maintain a strong visual focus. Despite this, Ferrell et al. (2008) stresses that it is difficult to conceive how the discipline of criminology could not be considered as "visual", as we live in an era where images of crime and deviance are frequently thrust into the public eye and consciousness through a rich variety of media sources-from true crime books, television shows, film and news outlets. In recent years, the significance of the image in relation to crime and deviancy has been increasingly recognised, particularly within the sub-discipline of cultural criminology. Whilst, as Ferrell (1999) highlights, cultural criminology has a vested interest in the analysis of visual data in relation to media representation of crime, such analysis and attention to the visual tends to be over-lapped with and, at times, neglected in favour of written narrative (Rafter, 2014). As such, there has been a void within the wider framework of criminology, and an apparent reluctance to focus explicitly on the visual representation of crime. Rafter (2014, p. 27) argues that "conventional criminology would have difficulty explaining the meanings of images". This is, according to Rafter, a reoccurring issue within the field of criminology. With countless numbers of visual representations of crime, a potentially large data set is being neglected which may provide a rich source for the further development of the discipline.

However, due to this increasing recognition of the significance of the visual, there has been a recent emergence of the sub-discipline "visual criminology". According to Rafter (2014, p. 129), "visual criminology is the study of the ways in which all things visual interact with crime and criminal justice, inventing and shaping one another". Visual criminology engages with the meaning, affect, symbolic power and spectacle of the "image", thus encouraging a critical engagement with and expansion of the criminological imagination (Hayward \& Presdee, 2010; Young, 2011). To fully engage with a visual criminological approach, visual analysis must be attuned to representation as well as the ways in which visual culture impacts upon individual and collective behaviour (Hayward, 2010).

Photography and the birth of the camera intersects with criminology in many ways, such as the traditional police photograph or "mug shot" (Carrabine, 2014) or less obvious examples, such as the fingerprint (Finn, 2009). The power of photographs lies in their ability to work denotatively, appearing to display real life events, as well as connotatively, visually representing larger hidden codes of meaning (Sekula, 1981, 1984; Barthes, 1977). Photographs are often understood as being a more objective form of representation, hence why they are often used in law enforcement and criminal identification (Finn, 2009; Marder, 2013). However, irrespective of the ability of the photograph to capture a "moment in time" and the consequential belief that this leads to an objective "truth", the subjective influence of the photographer on the end result has increasingly been recognised (Finn, 2009). Sekula (1981) challenged approaches to photography that ignored the social and political functions of images and exposed their ideological interplay in wider systems of classification, control and order. Furthermore, Ferrell and van de Voorde (2010, p. 41) argue that a photograph captures "not that of the people in front of the lens, nor that of the photographer, but of the shared cultural meaning created between the photographer and those photographed in a particular context". This highlights that the power of photographs lies in both their ability to display life events and on their conative ability to draw upon broad symbolic systems, visually representing hidden codes of meaning (Barthes, 1977). 
Particularly significant to this paper is the creation and use of the police mugshot. The original, 19th century goal of this type of photograph was to capture an accurate representation of a criminal's face and since this point in time, the mugshot permeates our daily lives in newspapers, on television and in film (Finn, 2009). The rise of photographic portraiture and the police mug shot during the 19th century was particularly relevant to the work of Lombroso (1876) and his theory of the "born criminal". Lombroso (1876) made direct links between the physical body and criminal propensity and by extension, captured this in its visual representation by deploying the "mugshot" as a key document in his work. Lombroso utilised images of "born criminals" in much of his work and also established a museum of criminal anthropology (Rafter, 2014). As highlighted by Rafter (2014, p. 130), "no criminologist has ever drawn more heavily on the visual, or revelled more in the imagery of crime".

Similarly to Lombroso, Bertillon also located criminality within the physical body. In the 19th century, he mobilized the mugshot into a system of classification, which enabled police officers to more effectively store and exchange criminal records (Finn, 2009). With this in mind, the intersection of crime and photography during this time period reinforced the notion that certain types of body are more prone to deviancy and thus visibly identifiable as "criminal". The use of photography and visual imagery within law enforcement practices reflect socially constructed categories of what constitutes criminality. As argued by Finn (2009, p. 30), "the criminal body was defined in terms that reflected racial and gender biases and that supported existing social theories and hierarchies". This exercise of power through law enforcement techniques reinforced the normalcy of the white, male body and consequently stigmatised other bodies as anomalous and therefore deviant (Finn, 2009). The androcentric prejudices which characterise the work of 19th century thinkers, such as Lombroso and Ferrero, continue to have a significant impact on the study of dominant images and understanding of female offending today (Lloyd, 1995). This notion of othering and deviant bodies is particularly significant to this paper, as the bodies of female offenders, by their very nature, are viewed to be deviant due to their contradiction of societal gendered expectations (Heidensohn, 1996; Jewkes, 2015). This is particularly relevant to crimes that contradict dominant images of the feminine ideal, such as female child sex offending.

\section{Visual Construction of Female Criminals}

Female offenders are often considered as being "doubly deviant, doubly damned" as they are not only judged for transgressing the criminal law, but more importantly, the laws governing acceptable forms of femininity (Lloyd, 1995). Due to the perceived abnormality of female offending (Naylor, 2001; Wykes, 1998; Young, 1999), journalists often use over simplistic and gendered discourses and language to "explain" female criminality (Jewkes, 2015). This mostly serves to represent such women as "other" and distinctly different to the rest of society. Othering emphasises polarizations, such as "insiders" and "outsiders", "normal", and "deviant" and thus serves to create distinct boundaries between "us", and "them", who are in this case female offenders. Young (1999, p. 104) argues essentialism is vitally important when creating "others", as "it separates out human groups on the basis of their culture or nature". This notion is particularly important for the current paper, as images of female offenders encourage the categorisation of "other" on the basis of physical appearance, thus again highlighting the continued influence and impact of Lombroso's (1893) work. Whilst all offenders are to some extent viewed to be "others", female criminals are more readily ascribed this label, due to the perceived abnormality of the female offender and the additional layer of gendered deviancy, in comparison to male counterparts (Heidensohn, 1996; Lloyd, 1995). 
Representations of female offenders often become entrenched with over-simplistic categories such as, "mythical monsters", "bad mother" and/or "mad" or "bad" (Ballinger, 2000; Jewkes, 2015; Jones \& Wardle, 2008). Those women who fall into the "mad" category are often portrayed as being unstable or hysterical, whereas those who are constructed as bad are viewed to be inherently evil and wilfully defiant of their gender role expectations (Berrington \& Honkatukia, 2002; Heidensohn, 1996; Lloyd, 1995). Dyer (1993, p. 14) argues that these representations encourage us to create overly simple "short-cuts" regarding explanations for female offending. Myers and Wight (1996) suggest that when a woman commits a criminal act, her sex is the principal factor through which all of her actions are seen and understood. They suggest that the sensationalised reporting of women's criminality can be viewed as a sign of social anxiety about women's roles and the demise of traditional femininity. In summary, in an effort to make criminal women's actions appear less of a concern to society, female offending is often individualised, pathologised and explained by over-simplistic and deterministic explanations such as being inherently evil or psychologically impaired (Myers \& Wight, 1996; Naylor, 2001; Barnett, 2006).

Such representations are particularly significant to crimes that contradict dominant and hegemonic understandings of femininity, such as female child sex offending. Female child sex offenders tend to be portrayed as evil women who have lost (or who never had) the female nurturing gene (Hayes \& Carpenter, 2013). While men who sexually abuse children may also be evil and monstrous they are not "unnatural" in the same way as women. Consequently, there is a sense of betrayal and fear that is not apparent in discussions about male sex offenders (Hayes \& Carpenter, 2013). Socially and culturally, we imbue women with the characteristics of warmth, care and nurture (Denov, 2003). It is therefore difficult to acknowledge and subsequently understand the female child sex offender.

Despite the growing body of literature which explores the construction and media representation of female offenders more broadly (For example, Jewkes, 2015; Barnett, 2006; Naylor, 2011; Grabe, Trager, Lear, \& Rauch, 2006), there has been little research which explicitly explores the visual representation of such women. An exception to this is Birch (1993), who argued that due to the medias' distinct and purposeful usage of imagery during the reporting of Myra Hindley, particularly the use of the now infamous mugshot, the image of her dyed blonde hair and impassive stare, connotes "modern affectless evil in a way that the contemporary photograph of Brady never has" (French, 1996, p. 38). Furthermore, Jones and Wardle (2009, p. 58) argue that the image of Hindley has become a "tool with which we understand and somehow comprehend the incompressible". In addition, Jones and Wardle (2008) explored the visual construction of Maxine Carr and demonstrated the "power" and influence that images in news can have on representation. Maxine Carr was convicted for perverting the course of justice in the Holly Wells and Jessica Chapman murder case in 2003. Her then partner, Ian Huntley, was charged with the murder of the two schoolchildren and Maxine Carr provided a false alibi for him on the night of their murder. Jones and Wardle (2008, p. 68) argue that the use and placement of images in the media representation of Maxine Carr led to a "total annihilation" of her character and consequently implied that she was "equally guilty" and an "equal partner" to Ian Huntley, in spite of her secondary role in the offending. Jones and Wardle (2008) conclude that the use of the "objective" press photograph acts as a mask for ideological bias and in cases of female offending, this becomes imbued with stereotypical and gendered motifs of female offenders.

However, much of the existing literature within this area locates the visual analysis of female offenders within a media representation context and considers the use of imagery in relation to image placement, page 
layout and against the wider backdrop of the women's representation. Furthermore, there has been no specific focus on the visual construction of female child sex offenders in the existing literature. Due to the disbelief that female child sex offenders exist (Denov, 2003) and the lack of understanding of this type of criminality, the visual portrayal of such women can arguably provide a useful insight into the dominant ways in which we attempt to make sense of such women. With this in mind, this paper applies a critical and reflexive approach to the visual construction of Vanessa George, challenging conventional criminological approaches, which privilege the written text over the spectacle of the image (Young, 2011; Pink, 2007; Hayward \& Presdee, 2010).

\section{A Critical, Reflexive Visual Methodological Approach}

Greer (2007) stresses that a lack of a firm methodological approach and understanding regarding the visual representation of crime can potentially result in criminologists ignoring key aspects regarding the social engagement and subsequent interpretation and understanding of crime and deviance at a public level:

...The visual constitutes perhaps the central medium through which the meanings and emotions of crime are captured and conveyed to audiences. Indeed, we would suggest that it is the visual that increasingly shapes our engagement with and understanding of, key issues of crime, control and order. (Greer, 2007, p. 5)

Whilst Greer refers to the visual as a general meaning towards a variety of visual sources including film, art, and photography, it is the latter that is the subject of analysis for this particular study.

Pink (2007) argues that visual analysis should be conducted reflexively and outlines a three stage approach to analysis. Firstly, Pink (2007) argues that it is impossible to gain an objective and "true" visual record of any process. Secondly, she suggests that the context of image production should be analysed to consider how visual content is informed by subjectivities. Finally, analysis should focus on the content of images, as well as the meanings that different individuals give to those images in different contexts (Pink, 2007). A method of analysis based loosely on Pink's (2007) suggestions is adopted in this paper. This analytical approach aims to deconstruct the image, as well as use the image as an entree into a discussion about the often over-simplistic and gendered construction of female child sex offenders.

The visual analysis is approached through a feminist lens, which seeks to interrogate the researcher's standpoint and explore latent content, both of which are "more amenable to the integration of feminist theory because of feminists' acceptance that taken-for-granted understandings of reality reinforce patriarchy" (Hardin \& Whiteside, 2010, p. 322; Barnett, 2006; Meyers, 1997). It is recognised that the meaning of the images analysed in this paper are overlaid by the authors own, personal interpretations and the endeavours of this paper are admittedly subjective (Walklate, Mythen, \& McGarry, 2011). However, the purposefully reflexive approach to analysis ensures that the interpretation of the image moves beyond what they mean in and of themselves and rather critically explores what they potentially imply about the wider construction of female child sex offenders. As highlighted by Pink (2007, pp. 118-119), analysis is not simply a matter of interpreting the visual content of images, but also involves "examining how different producers and viewers of images give subjective meanings to their content and form".

With this in mind, this paper seeks to critically consider how dominant images of female child sex offenders may represent the social processes that underpin the construction and public understanding of such women. The case study of Vanessa George, a nursery worker who was involved in the exchange of indecent imagery of children via an online paedophile ring, was analysed for this paper. This case study was selected for 
analysis, as this was a notorious case of female child sex offending in the UK that occurred in the last 10 years (George was convicted in 2009). Furthermore, imagery and photographs arguably played an important role in George's media representation. Her police mug-shot was widely circulated and various photographs of George at work (in her offending environment), were regularly utilised in various media sources, thus highlighting the significance of the visual to the wider representation of this particular case.

Whilst using a case study approach has been criticized due to its perceived lack of rigor and generalizability, Yin (2009) argues that the aim of case study research is to expand and generalise theories, not to enumerate frequencies. Furthermore, Flyvbjerg (2006, p. 226) argues that "formal generalization, whether on the basis of large samples or single cases, is considerably overrated as the main source of scientific progress" and the emphasis should instead be on the quality of the research. Additionally, case study methods are often criticized for containing bias towards verification, that is, a tendency to confirm the researchers preconceived notions. However, Flyvbjerg (2006) suggests that the question of subjectivism and bias applies to all methods, not just the case study. With this in mind, this paper recognizes the influence of researcher subjectivity and the lack of scientific generalizability. However, the critical, reflexive approach to analysis (Pink, 2007), and the use of this case study as an introduction into a discussion of the visual construction of female child sex offenders more generally, attempts to address some of these potential criticisms.

A selection of six images have been analysed in this paper, including two versions of George's police mugshots, both the original and close up version. In addition, four personal photographs of George have been analysed, which display her in her "natural" environment rather than in a controlled, criminal justice setting. These images were selected as they were the most widely used photographs of George which featured in the following newspapers from the date of her arrest (June 2009) to her conviction (December 2009): The Times, The Daily Mail, The Mirror, and The Guardian. The selected newspapers are each popular examples of its type (quality, middlebrow, and tabloid) and have a different audience demographic (Ellis, Sloan, \& Wykes, 2012, p. 7). Due to the photographs wide circulation, they arguably allude to the dominant ways in which George was visually constructed, particularly in a media context. It is significant to note that as well as analysing the photographs in and of themselves, the context and production of the images will also be critically considered. Furthermore, the images will be used as a tool to critically consider the wider construction and public understanding of female child sex offending. This will provide a clearer insight into the ways in which the visual serves to construct female child sex offenders within gendered motifs, thus providing a partial, over-simplistic "image" of such offending. The photographs were analysed individually, but for the purpose of this paper, two overarching themes have been identified.

\section{Findings: The Deviant Body}

The "doubly deviant" nature of female child sex offenders has been explored in relation to the written narrative (Denov, 2003; Hayes \& Carpenter, 2013; Hayes \& Baker, 2014) and similar gendered transgressions are also evident in the visual construction of Vanessa George. The overarching theme of "deviant bodies" details the ways in which the bodies of female child sex offenders, by their very nature, contradict and confuse idealised, dominant images of femininity and womanhood. This theme has been split into two sub-sections, namely, "female body in a male domain" and "physical attractiveness and the male gaze" to explore the differing, but overlapping ways in which George's body was constructed as "deviant" in the photographs analysed. 


\section{The "Female" Body in a "Male" Domain}

According to Carney (2010, p. 23), mugshots are not only an indication of policing power, but they also have the power to "brand" certain bodies with shame and stigma. Mugshots arguably reinforce the notion that certain types of body are more prone to deviancy and thus visibly identifiable as "criminal". At a basic analytical level, George's police mugshots, by their very existence, visually reinforce the deviant nature of George's body and criminality(See Figures 1 and 2).

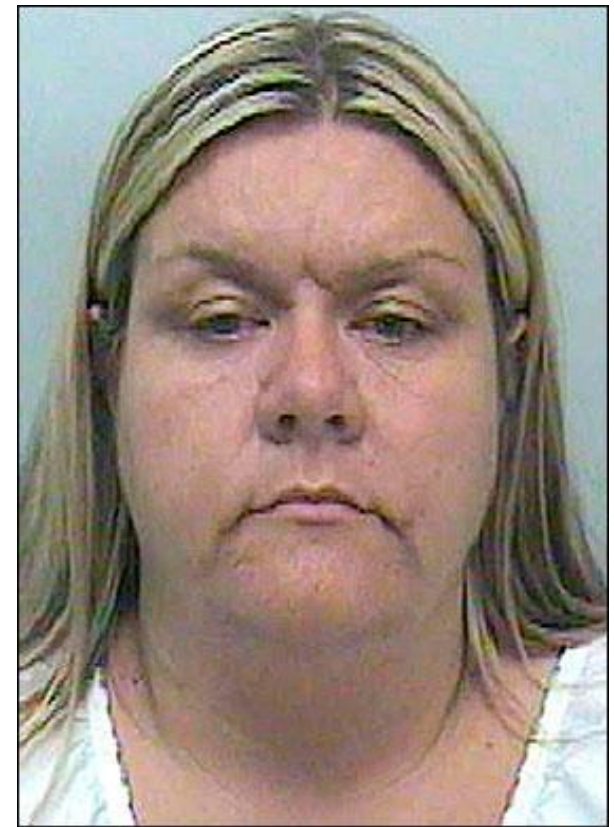

Figure 1. (2009). VG Image 1 (Photograph). In The Times (2009). The evil that women do; The Vanessa George case is another example of society not accepting that females can commit horrific crimes. 16th December.

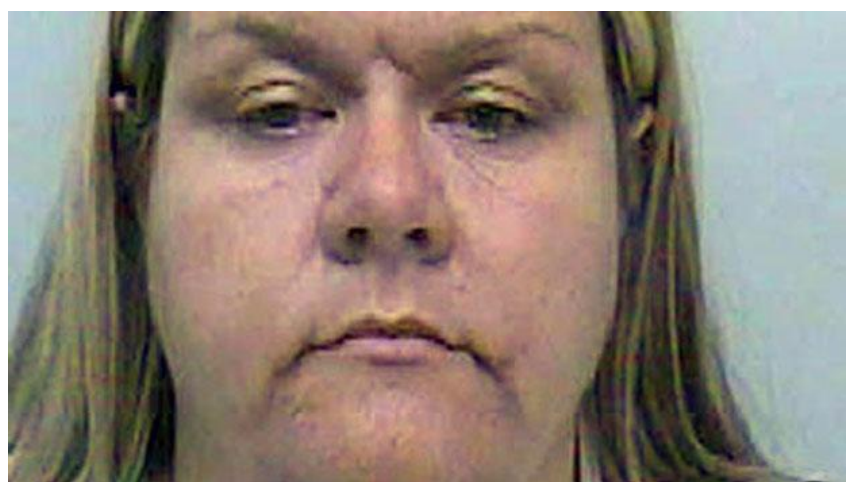

Figure 2. (2009). VG Image 2 (Photograph). In The Guardian (2009). Nursery paedophile case: The offenders: Connected online, abusers never met. 2nd October.

Man-as-perpetrator is the normative framework of child sex offences, therefore the context of George's mugshots (i.e., following her arrest for child sex offences) juxtaposed with the fact that she is a woman, serves to visually reinforce the disbelief of her involvement in such offending, consequently enhancing the discomfort of a woman engaging in a typically associated "male crime". According to Landor (2009), given that the vast majority of research on sex offenders fails to even contemplate the female sex offender, it is reasonable to conclude that in the public psyche as well as in the knowledge domains of the 
academic community, the sex offender is a male (Hayes \& Carpenter, 2013). Hayes and Baker (2014) argue that contradictions in written narratives of female sex offenders, between normative sex scripts(such as wife, mother, teacher) and "pariah femininities" (such as "predator" and "female paedophile"), serve to undermine traditional gender role expectations. Similarly, the mugshot of George visually highlights the incongruity between her sex, role as a nursery worker and the nature of her offending, thus visually emphasising the three-fold nature of her deviancy. Furthermore, the mugshots of George highlight the reality that this "monstrous" offender or woman exists, adding a sense of the real to that which may otherwise remain abstract. With this in mind, the mugshot of George, and other female sex offenders alike, arguably visually reinforces the anomaly of female sex offenders bodies whilst simultaneously reinforcing the normalcy of the male sex offender body (Finn, 2009).

A common discourse utilised in an attempt to make sense of female child sex offenders is to emphasise the lack of hegemonic or "ideal" feminine traits or qualities. This was also evident in a number of the images analysed of Vanessa George. For example, the two police mugshot photographs of George (see Figures 1 and 2) emphasise her typically masculine facial features, such as her dark eyes, large nose, burrowed brow and emotionless facial expression. The close proximity of the cropped version (see Figure 2) serves to emphasise George's masculinity by cropping out the majority of her hair, thus emphasising the aforementioned "masculine" facial features/expression. The use of lighting in the close up version of the mugshot particularly exaggerates the darkness of her eyes and mouth, thus further reinforcing the masculinity of the photograph. The dark lighting arguably encourages the association of concepts such as "predator" and "sinister", which are motifs typically associated with male sex offenders (Hayes \& Carpenter, 2013).

Whilst photographs are understood as being a more objective form of representation, the subjective influence of the photographer (Finn, 2009), the social and political functions of photographs (Sekula, 1981) and the shared cultural meaning created between the photographer and the photograph (Ferrell \& Van de Vorde, 2010) should be critically considered here. The deviancy of female offenders is often evidenced or emphasised in written text by their suggested lack of or unwillingness to display feminine qualities, characteristics or behaviours (For example, Berrington \& Honkatukia, 2002; Jewkes, 2015; Barnett, 2006). The emphasis on George's lack of femininity in her police mugshots suggests that similar techniques are evident in visual imagery as well. This suggests that the visual construction of female child sex offenders attempt to make sense of such offending by representing them as not "truly" woman and closer in nature to man. This in many ways echoes the work of Lombroso and Ferrero (1893), who argued that female offenders were similar to men in their physical characteristics and nature, thus distancing the idealised female body from deviancy and offending. It is argued in this paper that the continued influence of such simplistic explanations demonstrates the persistent unwillingness to engage with more nuanced explanations of female criminality, particularly child sex offending (Hayes \& Carpenter, 2013).

\section{Physical Attractiveness and The "Male Gaze"}

Certain aspects of femininity are favoured over others, such as slenderness and other such physical characteristics which satisfy the "male gaze" (Wykes \& Gunter, 2005). Jewkes (2015) argues that this notion extends to female offenders, particularly those who feature in news media. However, this often leads to the simplistic and deterministic categorisation of female offender's as either "conventionally attractive" or "conventionally unattractive". 
All of the images analysed of Vanessa George emphasise her large frame and weight, thus firmly placing her into the "conventionally unattractive" category. George's mugshots in particular (Figures 1 and 2), due to the close proximity of the image and the slightly upward angle of the camera, enhance and emphasise the size of her face and facial features. Furthermore, in VG Image 3 (Figure 3), the profile angle of the camera and George's laughing expression serves to enhance her double chin and her fitted clothes also further emphasise her large frame and weight. Similar observations are also evident in VG Image 4 (photo taken on the same occasion as Figure 3), with the drooping shoulders and close up, frontal angle of the camera serving to emphasise a rounded appearance.

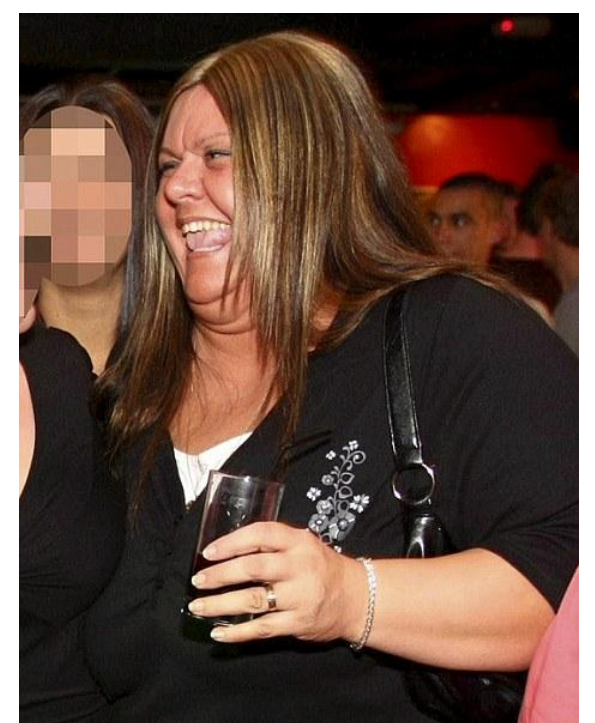

Figure 3. (2009). VG Image 3 (Photograph). In Daily Mail (2009). From a bubbly, happy mother to "your paedo whore mumma”. 16th December.

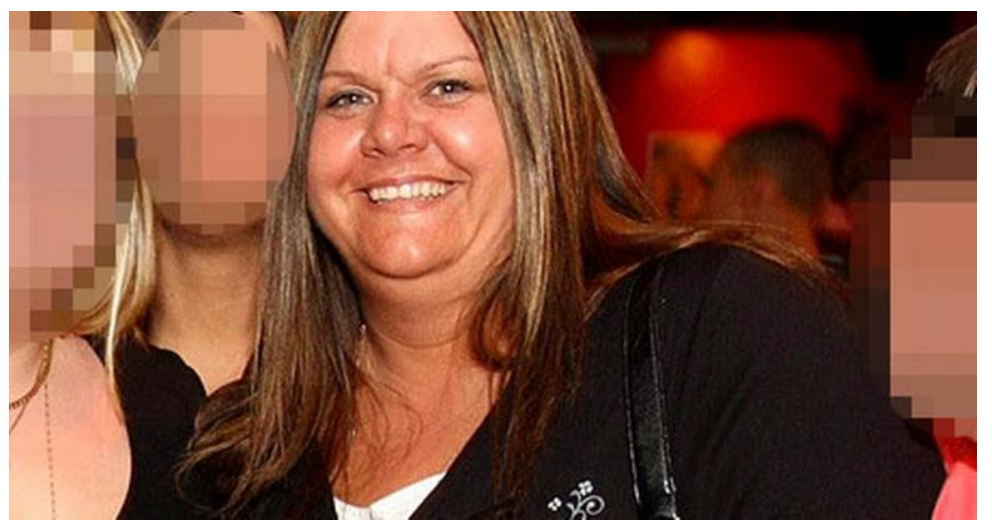

Figure 4. (2009). VG Image 4 (Photograph). In The Mirror (2009). Vanessa George's sickening police tapes. 13th October.

Mulvey (1999) argues that in a world ordered by sexual imbalance, the role of women is to be looked at and displayed by men, thus they must physically satisfy conventional modes of attractiveness as decided by the "male gaze". The ideal body functions as a discursive construct, where fatness emerges as a degenerate space of over-consumption, greed and laziness (Gullage, 2014). Hartley (2001, p. 65) argues that "because (fat women) do not construct bodies that conform to the feminine ideal, they are perceived as violating socially 
prescribed gender roles". Therefore, by emphasising Vanessa's weight, the photographs analysed here highlight that she does not satisfy the "male gaze" and is thus not attributed the characteristics of a feminine woman. Vanessa George contradicted the aesthetics of the feminine image due to her failure to adhere to the small, petite and non-threatening ideal (Orbach, 1978). The emphasis on Vanessa's weight ensured that her body was viewed to be deviant and "other", both due to her size, as well as her sex. Garland Thomson $(1997$, p. 8) argues that "those bodies deemed inferior become spectacles of otherness while the unmarked are sheltered in the neutral space of normalcy". Therefore, George's large frame creates a monstrous image, firmly representing her as a deviant "other" (Young, 1999). This is particularly relevant when considered within the wider context of her case, as "monster" or "beast" are common discourses which are used to explain and define female child sex offenders (Gavin, 2009; Hayes \& Baker, 2014).

The physical appearance of George highlights the degree to which dominant discourses of female offending continue to be associated with the Lombrosian view of criminality. Lombroso's belief that criminals could be identified by physical traits reinforces the notion of the deviant body. The bodies of female offenders, by their very nature, are viewed to be deviant due to their contradiction of societal gendered expectations (Heidensohn, 1996; Jewkes, 2015). By emphasising the weight and implied unattractiveness of George according to the male gaze, her physical appearance enhances her lack of adherence to gender role expectations, thus serving to distance the nature of her offending from idealised forms of femininity.

\section{"A Wolf in Sheep's Clothing"}

In continuing the position that female child sex offenders are often labelled as "monstrous" and lacking the female nurturing gene, Hayes and Baker (2014) argue that women are primarily normalised as the gatekeepers of sexuality and are subsequently seen as nurturers and protectors in positions of trust. As such, female child sex offenders challenge traditional gender roles dictated by hegemonic masculinity and femininity. Schippers (2007) terms these alternate femininities "pariah", because they are seen as socially toxic, shrouded in denial and taboo, and because they challenge the heteronormative reign of femininity and masculinity. Pariah femininities are not subordinate femininities but, rather, contaminants of idealized versions of femininity. Larson and Maison (1987) assert that, given our Judeo-Christian heritage, socially and as a culture we imbue women with the characteristics of warmth and nurturing. It is therefore difficult to acknowledge and subsequently detect the female child sex offender. It is here that the theme of the 'wolf in sheep's clothing' is introduced.

In VG Image 3 (see Figure 3), the emphasis on George's smile, the drink in her hand, and the handbag on her shoulder may appear to be of little consequence at first, but such images are used as a means to further reinforce the breaching of gender roles. This image and others alike (such as VG image $4 \& 5$ ) underpin the notion that these "monstrous others" can act or pretend to be "normal" whilst all along harboring ill intentions to those they are supposed to be protecting and nurturing, i.e., children. The use of such images, in particular Figure 5, serve as a means to illustrate to the viewer how this "wolf in sheep's clothing" can not only hide in plain sight, but to also reinforce the gross violation of the gender role(s) George was supposed to follow-these being nursery worker, mother and woman. Hayes and Baker (2014) note that written media narrative often uses phrases such as "child-minder", "mother", "teacher", "woman", and "wife"-all these words conjure up images of gendered stereotypes and behavioral expectations. These roles reinforce traditional sexual scripts of the female as passive, submissive, innocent, and nurturing. VG image 5 (Figure 5) which captures George at work and with newspaper pieces glued to her face, evokes similar stereotypes: 


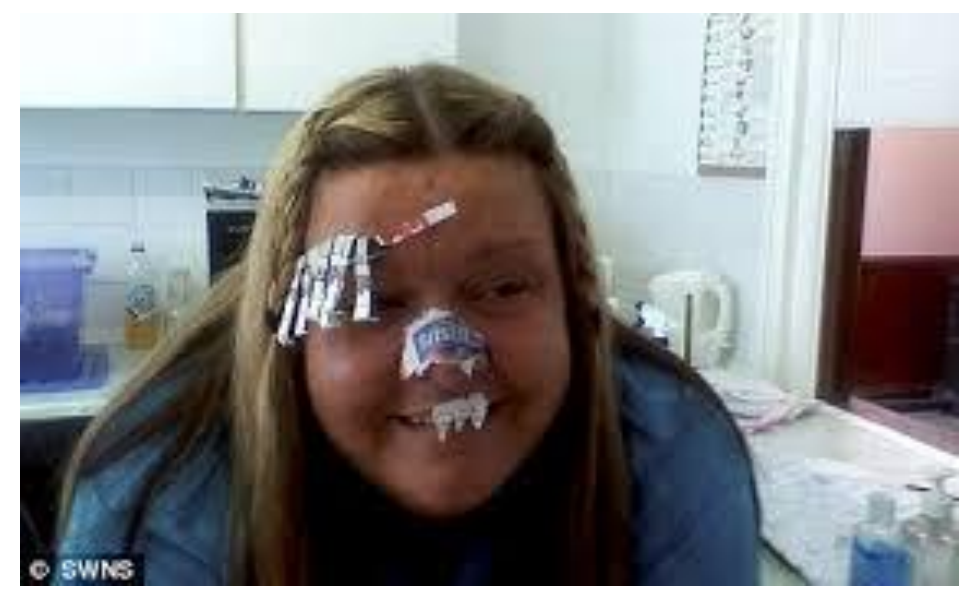

Figure 5. (2009). VG Image 5 (Photograph). In The Daily Mail (2009). Nursery monster Vanessa George to enjoy life of anonymity at taxpayers expense as furious parents fall for her to be "skinned and rolled in salt". 3rd October.

Upon first inspection, the above image of George at her place of work, a profession that very much embodies the gendered stereotypes that women are expected to engage in, combined with the playful smile she presents for the camera, arguably imbue such words as "carer" and "child-minder". This highlights the importance of context when analysing such imagery (Pink, 2007), as ordinarily, this photograph would represent a nurturing, playful woman at work in her caregiving role. Whilst, her implied lack of femininity is a clear focal point in the previously analysed police mug-shots, Figure 5 draws attention to George's more feminine qualities and roles. However, this does not deconstruct or challenge the othering of female sex offenders, but rather indirectly emphasizes George's betrayal and violation of how she should look, act, and subsequently behave. Whilst much of the visual representation of George focuses predominately on her lack of feminine qualities and evokes the sense of the "other", the visual landscape of female sex offenders appears to be, at least in part, shifting to the notion that the "other" can in fact "pretend" and outwardly adhere to idealized versions of femininity and womanhood, which arguably instills a sense of fear into the viewer/reader that such offenders may not always be clearly identifiable. Stevenson (2008, p. 112) claims that current media written narrative, in particular those found within the British press, has "effectively destroyed such fragile, albeit illusory, security" that women are incapable of the acts that George engaged in.

Furthermore, VG image 6 (Figure 6) which captures George facing away from the camera and standing over a group of sitting children, perhaps best represents both the notion of "other" and the shift towards the focusing on the more feminine qualities of female sex offenders. In particular, the juxtaposition between the emphasis of George's size, which towers and obscures some of the children, and the attention to her role as a carer, here emphasised by the context of the image, entwines both the notion of George as "other" while simultaneously evoking the sense that she is able to "masquerade" as a woman that embodies the traits and qualities expected from her. With this in mind, it may appear as though there is a move away, at least in part, from the notion of the "deviant body" in Figures 5 and 6 in particular, but these images in fact evoke the work of early theorists, such as Pollack (1950), who root women's offending within their pathology and argue that they are inherently deceitful. Furthermore, Pollack (1950) suggests that female offenders are able to manipulate more readily than their male counterparts, as criminal behavior is a deviation from normative gender role expectations. These connotations are present in both the photographs of George at work (Figures 5 and 6) and 
those when she is socializing with friends (Figures 3 and 4), thus highlighting that her suggested deceptive qualities were evident in all aspects of her life.

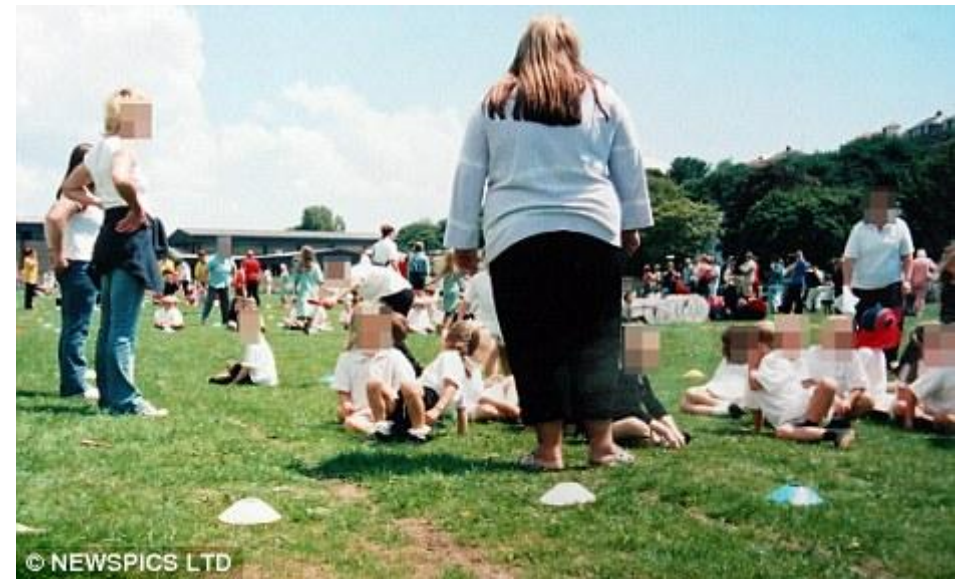

Figure 6. (2009). VG Image 6 (Photograph). In The Daily Mail (2009). Husband of nursery paedophile Vanessa George recovering at home after "suspected suicide attempt". 8th October.

Within VG images 3 and 4 (Figures 3 and 4), George could arguably be interpreted as a "working class woman", who is socializing with friends and drinking alcohol. Notwithstanding the previous discussion of the significance of context here, the connotations of a "working class woman" arguably serve to reinforce her deviancy. Hancock and Mooney (2011) note that the working class are "frequently assumed to be more feckless, immoral and criminally-inclined than more affluent groups in popular discourse" and that "middle class" crimes are less visible in the media than those of the working class (Hancock \& Mooney, 2011 cited in Harper, 2014, p. 92). Further to this, Nunn and Biressi (2008, p. 109) argue that those identified or characterised as working or underclass are "frequently ascribed a lesser value; they are marked as waste, un-modern, economically unproductive and socially peripheral". With this in mind, despite George attempting to "hide" herself as a "working class woman, the negative connotations of the working class, perpetuated by the conservative press" (Harper, 2014), only heightens her deceptive qualities, and further adds to her deviancy within the context of her class as well as her gender. Overall, the images of Vanessa George presented in this sub-section present her as outwardly embodying the gendered stereotypes of how a woman should look and behave, yet due to the context and usage of the images, this serves to emphasise George's ability to deceive.

\section{Concluding Comments}

Overall, the context of the photographs, i.e., a female child sex offending case, combined with the visual emphasis on George's weight, lack of femininity, working class identity and implied inherent ability to deceive collectively serve to represent George as "other". The images of George in and of themselves (with the exception of her police mug shot) could be interpreted as visually representing a social, working class woman and nursery teacher. This highlights the significance of context for the images of George analysed in this paper, as any photographs of her in her "normal" environment were arguably used as tools for media representatives to reinforce the unexplainable and unthinkable notion of a woman transgressing her expected gender roles by engaging in child sex offences.

The photographs of Vanessa George and arguably female child sex offenders more broadly, encourage the categorisation of "other" on the basis of physical appearance, thus highlighting the continued influence and 
impact of Lombroso's (1893) ideology. The "beastly" and "monstrous" connotations implied by the emphasis on George's weight in particular echoes familiar motifs and discourses evident in written narratives of female offending (Hayes \& Baker, 2014; Jewkes, 2015; Berrington \& Hokutukia, 2002). However, this paper argues that as well as constructing George as other on the basis of her "deviant body", her ability to deceive and present herself as a "normal" woman was simultaneously used as a tool to emphasise the threat of the female child sex offender, thus arguably reinforcing the moral panic often communicated in written narrative (Hayes \& Carpenter, 2013).

It is argued in this paper that the "spectacle of the image" (Rafter, 2014; Carrabine, 2014), combined with the gendered visual construction of Vanessa George, arguably influences the way in which the public understands female child sex offending more generally. This is particularly significant to note when the context and usage of the aforementioned photographs is considered, as each were the most dominant images of Vanessa George used in a news media context. Many scholars suggest that it is arguably the visual that increasingly shapes our engagement with and understanding of key issues related to crime and crime control (Greer, 2007; Hayward \& Presdee, 2010; Rafter, 2014). It is therefore argued in this paper that the connotative ability of photographs to draw upon broad, symbolic systems (Barthes, 1977) served to produce a gendered and at times monstrous image of George, which thus reinforced a partial, prejudicial and mythological image of female child sex offenders, rather than attempting to encapsulate a more nuanced explanation.

The mass circulation of photographs of female offenders, particularly in media, can arguably mark the body with shame and stigma. Whilst this has been discussed in relation to the mugshot (Carney, 2010), this paper argues that all photographs of female offenders circulated in media can potentially produce similar "marks" and consequent stigmatisation. This paper therefore concludes that, similar to the representation of female child sex offendersin written narrative (Hayes \& Carpenter, 2013; Hayes \& Baker, 2014; Gavin, 2009), the visual construction of George limits her to over-simplistic dichotomies, which are beset with myths and prejudices, thus adding to and reinforcing the limited and reductive understanding of female child-sex offending.

\section{References}

Ballinger, A. (2000). Dead woman walking. Aldershot: Ashgate.

Barnett, B. (2006). Medea in the media: Narrative and myth in newspaper coverage of women who kill their children. Journalism, 7, 411-432.

Barthes, R. (1977). Image-music-text. London: Fontana Press.

Berrington, E., \& Honkatukia, P. (2002). An evil monster and a poor thing: Female violence in the media. Journal of Scandinavian Studies in Criminology and Crime Prevention, 3, 50-72.

Birch, H (1993). If Looks could Kill: Myra Hindley and the Iconography of Evil. In Moving targets: Women, murder and representation. London: Virago Press.

Carney, P. (2010). Crime, punishment and the force of the photographic spectacle. In K. Hayward, \& M. Presdee (Eds.), Framing crime: Cultural criminology and the image. London: Routledge.

Carrabine, E. (2014). Seeing things: Violence, voyeurism and the camera. Theoretical Criminology, 18, 134-158.

Denov, M. S. (2003). The myth of innocence: Sexual scripts and the recognition of child sexual abuse by female perpetrators. Journal of Sex Research, 40, 303-314.

Dyer, R. (1993). The matter of images: Essays on representation. London: Routledge.

Ellis, A., Sloan, J., \& Wykes., M. (2012). "Moatifs" of masculinity: The stories told about "men" in British newspaper coverage of the Raoul Moat case. Crime, Media, Culture, 9, 3-21.

Ferrell, J. (1999). Cultural criminology. Annual Review of Sociology, 25, 395-418. 
Ferrell, J., \& Van de Voorde, C. (2010). The decisive moment: Documentary photography and cultural criminology. In K. Hayward, \& M. Presdee (Eds.), Framing crime: Cultural criminology and the image. London: Routledge.

Ferrell, J., Hayward, K., \& Young, J. (2008). Cultural criminology: An invitation. London: Sage.

Finn, J. (2009). Capturing the criminal image: From mug shot to surveillance society. Minnesota: University of Minnesota Press. Flyvbjerg, B. (2006). Five misunderstandings about case study research. Qualitative Inquiry, 12, 219-245.

Garland Thomson, R. (1997). Disability, identity, and representation: An introduction. In Extraordinary Bodies: Figuring Physical Disability in American Culture and Literature (pp. 5-15). Chichester University Press.

Gavin, H. (2009). "Mummy wouldn't do that" the perception and construction of the female child sex abuser. In Evil, Women and the Feminine, Budapest, Hungary.

Grabe, M., Trager, K. D., Lear, M., \& Rauch, J. (2006). Gender in crime news: A case study test of the Chivalry Hypothesis. Mass Communication and Society, 9, 137-163.

Greer, C. (2007). Newsmedia, victims and crime. In P. M. Davies, P. Francis, \& C. Greer (Eds.), Victim, crime and society. London: Sage.

Gullage, A. (2014). Fat Monica, Fat suits and friends. Feminist Media Studies, 14, 178-189.

Hancock, L., \& Mooney, G. (2011). Saints and scroungers: Constructing thepoverty and crime myth. Criminal Justice Matters, 83(1), 26-27.

Hardin, M., \& Whiteside, E (2010). Framing through a feminist lens: A tool in support of an active research agenda. In P. D’Angelo, \& J. Kuypers (Eds.), Doing framing analysis: Empirical and theoretical perspectives. London: Taylor Francis.

Harper. S. (2014). Framing the Philpotts. International Journal of Media \& Cultural Politics, 10(1), 83-98.

Hartley, C. (2001). Letting ourselves go: Making room for the fat body in feminist scholarship. In J. Evans Braziel, \& K. LeBesco (Eds.), Bodies out of bounds: Fatness and transgression (pp. 60-73). Los Angeles: University of California Press.

Hayes, S. \& Carpenter, B. (2013). Social moralities and discursive constructions of female sex offenders. Sexualities, 16(1-2), 159-179.

Hayes, S., \& Baker, B. (2014). Female sex offenders and pariah femininities: Rewriting the sexual scripts. Journal of Criminology, 2014, 1-8.

Hayward, K., \& Presdee, M. (2010). Framing crime: Cultural criminology and the image. London: Routledge.

Heidensohn, F. (1996). Women and crime (2nd ed.). Basingstoke: Macmillan.

Jewkes, Y. (2015). Media and crime (3rd ed.). London: Sage.

Jones, P., \& Wardle, C. (2008). "No emotion, no sympathy": The visual construction of Maxine Carr. Crime, Media and Culture, 4, 53-71.

Landor, R. (2009). Double standards? Representation of male vs. female sex offenders in the Australian Media. Griffith Working Papers in Pragmatics and Intercultural Communication, 2, 84-93.

Larson, L., \& Maison, S. (1987). Psychosexual treatment program for female sex offenders. St. Paul: Minnesota Correction Facility-Shakopee.

Lloyd, A (1995). Doubly deviant, doubly damned: Society's treatment of violent women. London: Penguin group.

Lombroso, C. (2006/1876). Criminal man. Durham, NC: Duke University Press.

Lombroso, C., \& Ferrero, G. (2004/1893). Criminal woman, the prostitute, and the normal woman. Durham, NC: Duke University Press.

Meyers, M. (1997). News coverage of violence against women: Engenerdering blame. Newbury Park: Sage.

Mulvey, L. (1999). Visual pleasure and narrative cinema. In L. Braudy, \& M. Cohen (Eds.), Film theory and criticism: Introductory readings. Oxford University Press.

Myers, A., \& Wight, S. (1996). No angels: Women who commit violence. London: Pandora.

Naylor, B. (2001). Reporting violence in the British print media: Gendered stories. The Howard Journal, 40, 180-194.

Nunn, H., \& Biressi, A. (2008). The undeserving poor. Soundings: A Journal of Politics and Culture, 41, 107-116.

Orbach, S. (1978). Fat is a feminist issue. London: Arrow Books.

Pink, S. (2007). Doing visual ethnography: Images, media and representation in research. London: Sage.

Pollack, O. (1950). The criminality of women. New York: A.S. Barnes.

Rafter, N. (2014). Introduction to special issues on visual culture and the iconography of crime and punishment. Theoretical Criminology, 18, 127-133.

Riggins, S. H. (1997). The language and politics of exclusion (pp. 1-30). Thousand Oaks, CA: Sage. 
Schippers, M. (2007). Recovering the feminine other: Masculinity, femininity, and gender hegemony. Theory and Society, 36(1), 85-102.

Sekula, A. (1981). The traffic in photographs. Art Journal, 41, 15-25.

Stevenson, K. (2008). She never screamed out and complained: Recognising gender in legal and media representations of rape. In J. Jones, A. Grear, R. A. Fenton, \& K. Stevenson (Eds.), Gender, sexualities and law (pp. 121-135). Oxon: Routledge. vanDijck, J. (2008). Digital photography: Communication, identity, memory. Visual Communication, 7, 57-76.

Walklate, S., Mythen, G., \& McGarry, R. (2011). Witnessing Wooton Bassett: An exploration in cultural victimology. Crime, Media, Culture, 7, 149-165.

Wykes, M. (1998). A family affair: The British press, sex and the wests. In C. Carter, G. Branston, \& S. Allen (Eds.), News, gender and power. London: Routledge.

Wykes, M., \& Gunter, B. (2005). The media and body image: If looks could kill. London: Sage.

Yin, R. K. (2009). Case study research: Design and methods. London: Sage.

Young, J. (1999). The exclusive society. London: Sage.

Young, J. (2011). The criminological imagination. Cambridge: Polity Press. 